\title{
ESTIMATION OF SERUM CALCIUM AND MAGNESIUM IN PREECLAMPSIA AND ECLAMPSIA
}

\author{
Mahendra Patwari ${ }^{1}$, Bharat Talukdar², Neiluotuonuo Solo 3
}

1 Professor and HOD, Department of Obstetrics and Gynaecology, FAA Medical College, Barpeta, Assam. ${ }^{2}$ Assistant Professor, Department of Obstetrics and Gynaecology, FAA Medical College, Barpeta, Assam. ${ }^{3}$ Post Graduate Trainee, Assam Medical College, Dibrugarh, Assam.

\section{ABSTRACT}

\section{BACKGROUND}

How pregnancy incites or aggravates hypertension remains unsolved despite decades of intensive research. The levels of calcium and magnesium in pregnancy may implicate their possible role in preeclampsia and eclampsia.

\section{OBJECTIVE}

In this study, serum levels of calcium and magnesium were evaluated in preeclampsia and eclampsia women compared to normal pregnancy.

\section{METHODOLOGY}

A total of 200 subjects were involved in the study. Group A consisting of 100 normotensive pregnant women and Group B consisting of 50 preeclampsia and 50 eclampsia patients. Data were gathered using a structured proforma. Venous blood samples were drawn for the estimation of calcium and magnesium.

\section{RESULTS}

Women with Group B (Preeclampsia and eclampsia) had significantly lower serum calcium and magnesium levels than those in the control group $(\mathrm{p}<0.0001 \mathrm{each}$ ). Also, these mineral levels were significantly decreased in eclampsia compared to preeclampsia. Two maternal deaths were recorded in eclamptic women. There were $73 \%$ live births, $9 \%$ still births and $18 \%$ neonatal deaths in preeclampsia and eclampsia groups. Both calcium and magnesium levels are significantly decreased in those patients who develop complications in the preeclampsia and eclampsia group compared to normotensives.

\section{CONCLUSION}

In this study population, serum calcium and magnesium levels are lower in preeclampsia and eclampsia than in normal pregnancy.

\section{KEYWORDS}

Preeclampsia, Eclampsia, Calcium, Magnesium.

HOW TO CITE THIS ARTICLE: Patwari M, Talukdar B, Solo N. Estimation of serum calcium and magnesium in preeclampsia and eclampsia. J. Evolution Med. Dent. Sci. 2016;5(58):3985-3987, DOI: 10.14260/jemds/2016/912

\section{INTRODUCTION}

Preeclampsia is a progressive, multisystemic disorders characterised by triad of high blood pressure to the extent of $140 / 90 \mathrm{mmHg}$ or more, proteinuria and with or without oedema developing after 20 weeks of pregnancy. ${ }^{1}$ Eclampsia is the occurrence of convulsion in association with signs and symptoms of preeclampsia. The pathophysiological mechanism is characterised by a failure of the trophoblastic invasion of the spiral arteries, which may be associated with an increased vascular resistance to the uterine artery and a decrease perfusion of the placenta. ${ }^{2}$ But the exact aetiology is still unknown, various hypothesis in the occurrence of preeclampsia have been set including the increase in thromboxane levels and the decrease in $\mathrm{PGI}_{2}$ levels as well as an imbalance of lipid peroxidise and antioxidants. However, the results from many clinical studies show the relationship

Financial or Other, Competing Interest: None.

Submission 11-06-2016, Peer Review 08-07-2016,

Acceptance 13-07-2016, Published 19-07-2016.

Corresponding Author:

Dr. Mahendra Patwari,

Professor and HOD,

Department of Obstetrics and Gynaecology,

FAA Medical College,

Barpeta, Assam.

E-mail: drpatwari52@gmail.com

DOI: $10.14260 /$ jemds $/ 2016 / 912$ between the aggravation of the hypertension complications and the change in the concentration of various chemicals in the mother's serum. ${ }^{3}$ Interestingly, significant reduction in serum calcium and magnesium are found in pre-eclamptic mothers. ${ }^{4}$ Decreased serum calcium may trigger high blood pressure by stimulating renin release and parathyroid hormone secretion and also by causing vasoconstriction by its effect on vascular smooth muscle. Magnesium has been known as an essential cofactor for many enzymes and it plays an important role in peripheral vasodilatation.

Now-a-days eclampsia is considered as a multi-nutritional related disease. Attention has turned in recent years towards identifying maternal markers, which are changed in women who go on to develop preeclampsia and eclampsia which has been used in the prediction of preeclampsia and explore future areas of investigations. This study was done to estimate the serum calcium and magnesium level in preeclampsia and eclampsia with foeto-maternal outcomes.

\section{METHODOLOGY}

This prospective study was carried out in the Department of Obstetrics and Gynaecology in collaboration with Department of Biochemistry of Medical College during the period from $1^{\text {st }}$ July 2012 to $31^{\text {st }}$ June 2013. The study was approved by Institutional Ethical Committee. Study population was divided 
into two groups. Group A (Control Group) consisting of 100 numbers of normotensive pregnant women after completing 20 weeks of gestation and Group B (Study Group) consisting of 50 preeclampsia and 50 eclampsia patients. They were selected randomly by lottery method. Selection of cases in Group B was done after fulfilling the inclusion criteria.

\section{Inclusion Criteria}

1. Pregnant woman presenting with antepartum and intrapartum eclampsia.

2. Gestational age more than 20 weeks.

3. Blood pressure $\geq 140 / 90 \mathrm{mmHg}$.

4. Occurrence of convulsion with or without subsequent loss of consciousness.

5. Proteinuria $\geq 1+$ on dipstick in the random urine sample.

\section{Exclusion Criteria}

1. Patients with convulsions due to causes other than eclampsia.

2. Previous history of hypertension and renal disease.

3. Postpartum eclampsia.
Blood samples were collected before magnesium sulphate was given for the treatment of Group B patient. Those patients who had received magnesium sulphate from referral centres were excluded. The estimation of magnesium and calcium was done by Calmagite and Arsenazo 3 method with normal reference value for adult was $1.8-3.0 \mathrm{mg} / \mathrm{dL}$ and $8.4-10.4$ $\mathrm{mg} / \mathrm{dL}$ respectively. After taking samples, treatment by magnesium sulphate was done where indicated like convulsion and imminent eclampsia. All the patients were followed up till discharge from the hospital. Data were taken in structured proforma and analysis was done using relevant statistical tools.

\section{RESULTS AND OBSERVATIONS}

There were no significant statistical differences between the study and control group regarding the age, parity, socioeconomic status, antenatal visit, gestational age and mode of delivery. In both the groups, maximum patients delivered vaginally. The commonest indication of caesarean section in both Group A and Group B was foetal distress followed by induction failure.

\begin{tabular}{|c|c|c|c|c|c|c|}
\hline \multirow{2}{*}{ Groups } & \multicolumn{3}{|c|}{ Serum Calcium (mg/dL) } & \multicolumn{3}{|c|}{ Serum Magnesium (mg/dL) } \\
\hline & Mean \pm SD & t - value & P value & Mean \pm SD & t - value & $P$ - value \\
\hline Group A $(\mathrm{N}=100)$ & $9.52 \pm 1.15$ & \multirow{2}{*}{10.3294} & \multirow{2}{*}{$<0.0001^{*}$} & $2.385 \pm 0.514$ & \multirow{2}{*}{12.0304} & \multirow{2}{*}{$<0.0001^{*}$} \\
\hline Group B $(\mathrm{N}=100)$ & $8.20 \pm 0.54$ & & & $1.616 \pm 0.38$ & & \\
\hline Preeclampsia $(\mathrm{N}=50)$ & $8.38 \pm 0.52$ & \multirow[b]{2}{*}{2.77} & \multirow[b]{2}{*}{$0.0067^{*}$} & $1.79 \pm 0.26$ & \multirow[b]{2}{*}{5.09} & \multirow[b]{2}{*}{$<0.0001^{*}$} \\
\hline $\begin{array}{c}\text { Eclampsia } \\
(\mathrm{N}=50)\end{array}$ & $8.02 \pm 0.49$ & & & $1.44 \pm 0.41$ & & \\
\hline \multicolumn{7}{|c|}{ P value $<0.05$ considered significant, ${ }^{*}=$ Significant } \\
\hline & Table 1: & parisonot & ium and $N$ & sium Level & & \\
\hline
\end{tabular}

Table 1 shows that there is a significant decrease in the calcium and magnesium level in the preeclampsia and eclampsia group (Group B) compared to normotensives (Group A). In preeclampsia and eclampsia group also the value of calcium and magnesium are significantly lower in eclampsia $(\mathrm{p}<0.05)$.

\begin{tabular}{|c|c|c|}
\hline Complications & Group A (\%) & Group B (\%) \\
\hline Septicaemia & - & $1(2.22 \%)$ \\
\hline Pulmonary oedema & - & $2(4.45 \%)$ \\
\hline Abruption & $4(26.67 \%)$ & $4(8.89 \%)$ \\
\hline Wound infection & $6(40 \%)$ & $5(11.11 \%)$ \\
\hline CVA & - & $1(2.22 \%)$ \\
\hline PPH & $5(33.33 \%)$ & $24(53.34 \%)$ \\
\hline HELLP Syndrome & - & $1(2.22 \%)$ \\
\hline Retinal detachment & - & $1(2.22 \%)$ \\
\hline ARF & - & $2(4.45 \%)$ \\
\hline Postpartum psychosis & - & $1(2.22 \%)$ \\
\hline Cerebral oedema & - & $1(2.22 \%)$ \\
\hline Neurological deficit & - & $1(2.22 \%)$ \\
\hline DIC & - & $1(2.22 \%)$ \\
\hline Total & $\mathbf{1 5 ( 1 0 0 \% )}$ & $\mathbf{4 5 ( 1 0 0 \% )}$ \\
\hline Table 2: Maternal Complications \\
\hline \multicolumn{2}{|c}{}
\end{tabular}

Maternal complications were more in Group B (N=45) compared to normotensive group $(\mathrm{N}=15)$. The commonest complication in Group A was wound infection. In group B the commonest complication was post-partum haemorrhage (PPH) (53.34\%) followed by wound infection (11.11\%).

\begin{tabular}{|c|c|c|}
\hline Complications & Group A (\%) & Group B (\%) \\
\hline Pre-term & $3(17.64 \%)$ & $22(27.86 \%)$ \\
\hline Birth asphyxia & $1(5.89 \%)$ & $8(10.11 \%)$ \\
\hline IUD & $2(11.76 \%)$ & $9(11.39 \%)$ \\
\hline IUGR & $1(5.89 \%)$ & $9(11.39 \%)$ \\
\hline Septicaemia & - & $5(6.33 \%)$ \\
\hline Weight <2.5 kg & $10(58.82 \%)$ & $26(32.92 \%)$ \\
\hline Total & $\mathbf{1 7}(100 \%)$ & $\mathbf{7 9 ( 1 0 0 \% )}$ \\
\hline \multicolumn{2}{|c|}{ Table 3: Foetal Complications } \\
\hline
\end{tabular}

Foetal complications were more in Group B $(\mathrm{N}=79)$ compared to group A $(\mathrm{N}=17)$. Table 3 shows that in normotensive mothers commonest foetal complication was birth weight $<2.5 \mathrm{~kg}$. In group $\mathrm{B}$, commonest foetal complication was weight $<2.5 \mathrm{~kg}$ followed by preterm delivery.

\begin{tabular}{|c|c|c|c|c|c|c|}
\hline \multirow{2}{*}{ Groups } & \multicolumn{2}{|c|}{ Serum Calcium (mg/dL) } & \multicolumn{3}{c|}{ Serum Magnesium (mg/dL) } \\
\cline { 2 - 5 } & Mean \pm SD & t - value & P - value & Mean \pm SD & t - value & P - value \\
\hline Patients who developed complications in Group A & $9.52 \pm 1.15$ & \multirow{2}{*}{7.7168} & $<0.0001^{*}$ & $2.38 \pm 0.51$ & \multirow{2}{*}{9.8354} & $<0.0001^{*}$ \\
\cline { 2 - 2 } & & $1.53 \pm 0.41$ & \\
\hline Patients who developed complications in Group B & $8.14 \pm 0.50$ & & & \\
\hline
\end{tabular}


Table 4 shows that the calcium and magnesium level is significantly reduced in those cases that developed complications in the preeclampsia and eclampsia group (Group B) compared to the normotensive (Group A). Two maternal deaths were found in Group B and both were eclamptic patients. Out of the 2 deaths, one was due to CVA and the other was due to pulmonary oedema.

\section{DISCUSSION}

From the present study, it was found that there is a significant decrease in the calcium and magnesium levels in the preeclampsia and eclampsia patients compared to normotensive women $(\mathrm{p}<0.0001)$. Also, observed is that there is a significant decrease in the levels of calcium and magnesium in those patients who developed complications in the study group compared to the control group $(p<0.0001)$. The level of both calcium and magnesium is significantly more decreased in eclampsia than preeclampsia $(p=0.0067)$. Similar findings were reported by Idogun ES et $\mathrm{al}^{5}$ 2007, in preeclampsia and eclampsia both serum calcium and magnesium levels were found to be decreased compared to normotensive women, though decrease in magnesium level was not significant. R Akhter et al $^{6} 2009$ reported that the level of magnesium was significantly decreased in eclamptic patients compared to normotensive women. Gupta D et al ${ }^{7}$ 2013 reported that there is a significant decrease in the level of serum magnesium and calcium in both preeclampsia and eclampsia compared to normal pregnant and non-pregnant women.

In the present study there were 2 maternal deaths in eclampsia group, 1 died due to CVA and the other due to pulmonary oedema. In a study done by Marina Khanum. ${ }^{8}$, there were 2 maternal deaths, 1 from acute renal failure and other from CVA. Savita Rani Singhal. ${ }^{9}$ reported 8 maternal deaths, 4 were due to pulmonary embolism, 2 from DIC, 1 from HELLP syndrome and 1 due to pulmonary oedema. The differences in the maternal mortalities with different studies may be due to small sample size and most of the patients who expired were excluded from the study as majority of these patients had received magnesium sulphate from the referral centres.

In the present study, $73 \%$ of the neonates were alive and healthy on discharge, but there was $9 \%$ still births and $18 \%$ neonatal deaths in preeclampsia and eclampsia group. Edgar M et al ${ }^{10} 2012$ reported $79.3 \%$ neonates healthy and alive, $12.2 \%$ still birth and $8.5 \%$ neonatal deaths. Marina Khanum et al 2004 also reported 66\% living neonates, 21\% still births and $17 \%$ neonatal deaths, which are almost similar to the present study.

\section{CONCLUSION}

By estimation of serum calcium and magnesium level in preeclampsia and eclampsia patients in the present study, it has been found that both are significantly reduced compared to normotensive women. However, it remains unknown whether these changes are a cause or a consequence of the disease. All these observation require further confirmation by carrying out a study with a large sample size.

\section{REFERENCES}

1. Cunninghams FG, Leveno KJ, Bloom SL, et al. Williams Obstetrics. 24th ed. New York: McGraw Hill 2014.

2. Phupong V, Dejthevaporn T, Tanawattanacharoen S, et al. Predicting the risk of preeclampsia and small for gestational age infants by uterine artery doppler in low risk women. Arch Gynecol Obstet 2003;268(3):158-61.

3. Orhan H, Onderoglu L, Yucel A, et al. Circulating biomarkers of oxidative stress in complicated pregnancies. Arch Gynecol Obstet 2003;267(4):189-95.

4. Standley CA, Whitty JE, Mason BA, et al. Serum ionized magnesium levels in normal and preeclamptic gestation. Obstet Gynecol 1997;89(1):24-7.

5. Idogun ES, Imarengiaye CO, Momoh SM. Extracellular calcium and magnesium in preeclampsia and eclampsia. African Journal of Reproductive Health 2007;11(2):8994.

6. Akther $\mathrm{R}$, Rashid M. Is low level of serum ionized magnesium responsible for eclampsia? J BD Coll Phys Surg 2009;27(2):76-81.

7. Gupta D, Verma M. Study of serum calcium, magnesium and urine microalbumin level in normal and preeclamptic gestation and to compare with nongestational value. Journal of evolution of medical and dental sciences 2013;2(6):213-18.

8. Khanum M, Ashra F, Sahrin H. A clinical study of 100 cases of eclampsia in rajshahi medical college hospital. TAJ: Journal of Teachers Association 2004;17(2):80-3.

9. Singhal SR, Anshu, Deepika, et al. Maternal and perinatal outcome in severe preeclampsia and eclampsia. Journal of South Asian Federation of Obstetrics and Gynaecology 2009;1(3):25-8.

10. Edgar MN, Kihunrwa A, Rumanyika R, et al. Maternal and perinatal outcomes among eclamptic patients admitted to bugando medical centre, Mwanza, Tanzania. Afr J Reprod Health 2012;16(1):35-41. 